九州大学学術情報リポジトリ

Kyushu University Institutional Repository

\title{
A Revision of the Subgenus Plastandrena of the Genus Andrena of Eastern Asia (Hymenoptera : Apoidea : Andrenidae)
}

Xu, Huan-Li

Department of Entomology, College of Agronomy and Biotechnology, China Agricultural University

Tadauchi, Osamu

Laboratory of Entomology, Division of Zoology \& Entomology, Department of Applied Genetics and Pest Management, Faculty of Agriculture, Kyushu University

https://doi.org/10.5109/19638

出版情報：九州大学大学院農学研究院紀要. 56 (1)，pp.63-66，2011-02. Faculty of Agriculture， Kyushu University

バージョン :

権利関係 : 


\title{
A Revision of the Subgenus Plastandrena of the Genus Andrena of Eastern Asia (Hymenoptera: Apoidea: Andrenidae)
}

\author{
XU Huan-li* and Osamu TADAUCHI
}

\author{
Laboratory of Entomology, Division of Zoology \& Entomology, Department of Applied Genetics and \\ Pest Management, Faculty of Agriculture, Kyushu University, \\ Fukuoka 812-8581, Japan \\ (Received October 29, 2010 and accepted November 8, 2010)
}

\begin{abstract}
The subgenus Plastandrena of the genus Andrena from eastern Asia is revised and six species are recognized. Andrena (Plastandrena) fukaii Cockerell is recognized as a new synonym of A. japonica Smith, and A. (Plastandrena) eversmanni Radoszkowski, A. (Plastandrena) magnipunctata Kim et Kim and A. (Plastandrena) transbaicalica Popov are recorded from China for the first time. A key to East Asian species of Plastandrena is given.
\end{abstract}

\section{INTRODUCTION}

The subgenus Plastandrena was erected by Hedicke in 1933. It is distinctly separated from the other subgenera by having the propodeal enclosure coarsely wrinkled, usually with a transverse carina posteriorly, and it also has the hind tibial spur widened and curved at the base. It is similar to the subgenus Trachandrena Roberston in having the coarsely sculptured propodeal enclosure and the black clypeus in male. However, it is different from Trachandrena which has the strongly narrowed facial fovea in the lower half and the broad inner space near the compound eyes, the normal hind tibial spur, and the sixth sternum flattened apically in male. Popov (1949) synonymized Schizandrena Hedicke with Plastandrena and he (1958) gave a key to 28 Eurasian species and subspecies in this subgenus. In Europe, Warncke (1968) synonymized two subgenera Glyphandrena Hedicke and Mitsukuriella Hirashima et LaBerge with Plastandrena. He included six species in this subgenus. In eastern Asia, Yasumatsu (1941) listed six species, A. bimaculata mondaensis Friese, $A$. carbonaria (L.), A. eversmanni Radoszkowski, A. fukaii Cockerell, A. japonica (Smith) and A. mongolica Morawitz from Mongolia and Japan. Hirashima (1957) described a new species $A$. (Plastandrena) astragalina from Japan. Hirashima and LaBerge (1965) erected a new subgenus Mitsukuriella based on A. japonica. Wu (1965) recorded $A$. carbonaria from China and (1982) recorded $A$. (Plastandrena) ferghanica (=A. mongolica) and described a new species $A$. (Plastandrena) himalayaensis (=A. (Andrena) himalayaensis) from Tibet, China. In Russian Far East Osytshnjuk (1995) gave a key to three species in this subgenus, $A$. (Plastandrena) dzynnanica, A. (Plastandrena) carboniria and $A$. (Plastandrena) transbaicalica. Tadauchi and Matsumura (2007) described one new species from Nepal and Tadauchi (2008) recorded five species from

* Department of Entomology, College of Agronomy and Biotechnology, China Agricultural University, Beijing 100193, China

* Corresponding author (E-mail: hanabati@cau.edu.cn)
Central Asia. The Holarctic Plastandrena is represented by 26 species in Palaearctic region and six species in Nearctic region (Gusenleitner \& Schwarz, 2002). In this study, we examined species deposited in the Institute of Zoology, Academia Sinica and the Entomological Laboratory, Kyushu University, and recognized six species of Plastandrena from eastern Asia. We synonymized $A$. fukaii Cockerell with $A$. japonica (Smith) and recorded $A$. eversmanni Radoszkowski, $A$. magnipunctata Kim et Kim and $A$. transbaicalica Popov from China for the first time. Two species of $A$. (Plastandrena) eoa Popov from north China and $A$. (Plastandrena) dzynnania Popov from east Turkestan are excluded from this study because we have no materials at hands. A key to East Asian species of Plastandrena is given. Specimens were borrowed from the Institute of Zoology, Academia Sinica (Beijing) and the Entomological Laboratory, Kyushu University (Fukuoka).

\section{Subgenus Plastandrena Hedicke}

Plastandrena Hedicke, 1933, Mitt. Zool. Mus. Berlin, 19: 217-218; Hirashima, 1952, Mushi, 24 (10): 63; Popov, 1958, Horae Soc. Ent. Union. Sovet., 46: 127; LaBerge, 1964, Univ. Nebraska St. Mus. Bull., 4: 297-298; Warncke, 1968, Mem. Est. Mus. Zool. Univ. Coimbra, (307): 55-56; LaBerge, 1969, Trans. Amer. ent. Soc., 95: 2-3. Type species: Melitta tibialis Kirby, 1802, by original designation.

Schizandrena Hedicke, 1933, Mitt. Zool. Mus. Berlin, 19: 218. Type species: Andrena aulica Morawitz, 1876 = Melitta bimaculata Kirby, 1802, by original designation.

Mitsukuriella Hirashima et LaBerge, 1965, J. Fac. Agr., Kyushu Univ., 13: 472. Type species: Nomia japonica Smith, 1873, by original designation.

Mitsukuriapis Hirashima, LaBerge et Ikudome, 1994, Bull. Kagoshima Women's Junior College, 29: 6, new name for Mitsukuriella Hirashima et LaBerge 1965 (nec. Mitsukuriella Heding et Panning, 1954).

Glyphandrena Hedicke, 1933, Mitt. Zool. Mus. Berlin, 19: 212. Type species: Apis carboniria Linnaeus, 
1767, by original designation.

Diagnosis: Moderate to large-sized bees; facial quadrangle broader than long; integument metallic or not; clypeus black; pronotum without humeral angle and ridge; propodeal enclosure coarsely wrinkled with posterior carina or not; lateral area of propodeum usually rugulated; posterior spur of hind tibia broadened and abruptly bent near base; metasomal terga punctate with apical hair bands or not. Male clypeus black in Palaearctic species, metasomal sterna with incomplete subapical fimbriae, sixth sternum with strong reflected lateral teeth.

\section{Key to species of the subgenus Plastandrena in eastern Asia}

\section{Female}

1. Metasomal terga without hair bands or with only lat-

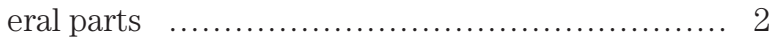

- Metasomal terga with hair bands $\ldots . . . \ldots \ldots \ldots \ldots . . . . .4$

2. Integument with pure brown to black hairs except hind femoral and tibial scopa white

pilipes (Fabricius)

- Integument at least with pale hairs ................ 3

3. Metasomal terga densely punctate, extremely reflected (1st generation), less reflected (2nd generation) apically; clypeus with median irregular impunctate space ........................ japonica (Smith)

- Metasomal terga sparsely and weakly punctate, posterior depression flat; clypeus without median impunctate space ..................... transbaicalica Popov

4. Metasomal terga 1-4 with broad, decumbent white hair bands; propodeal enclosure weakly wrinkled with weak transverse posterior carina; [facial fovea white, head and thorax with abundant white hairs; clypeus closely punctate; process of labrum small, entire] .......................... eversmanni Radoszkowski

- Metasomal terga with short yellow or white hair bands; propodeal enclosure strongly wrinkled with transverse posterior carina $\ldots \ldots \ldots \ldots \ldots \ldots \ldots \ldots . . . \ldots$

5. Metasomal terga 1-3 red in part; terga with short, erect hairs and minute punctures; clypeus dulled with or without median raised impunctate line mongolica Morawitz

- Metasomal terga black; terga with scanty hairs and moderate punctures; clypeus shiny without impunctate space $\quad . . . . . . . . . .$. magnipunctata Kim et Kim

\section{Male}

1. Metasomal terga without hair bands or with only lat-

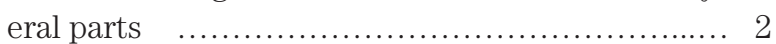

- Metasomal terga with hair bands $\ldots . . . \ldots \ldots \ldots \ldots . . .44$

2. Head, propodeum and metasoma with pure brown to black hairs ..................... pilipes (Fabricius)

- Head, propodeum and metasoma at least with pale

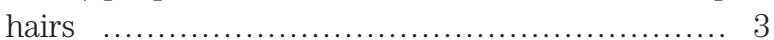

3. Metasomal terga densely punctate, extremely reflected (1st generation), less reflected (2nd generation) apically; propodeal enclosure strongly wrinkled japonica (Smith)
- Metasomal terga sparsely and weakly punctate, posterior depression flat; propodeal enclosure weakly wrinkled ............................ transbaicalica Popov

4. Metasomal terga reddened in part ................ 5

- Metasomal terga black; [terga with scanty hairs and moderate punctures; clypeus shiny without impunctate space] .............. magnipunctata Kim et Kim

5. Propodeal enclosure weakly wrinkled with weak transverse posterior carina; metasomal terga with dense minute punctures

eversmanni Radoszkowski

- Propodeal enclosure strongly wrinkled with transverse posterior carina; metasomal terga with sparse minute punctures ................ mongolica Morawitz

\section{Andrena (Plastandrena) pilipes (Fabricius)}

Apis pilipes Fabricius, 1781, Spec. Insect., 1: 474 [female, Italy].

Andrena pilipes: Morawitz, 1880, Bull. Biol. Acad. Sci. St. Petersbourg, 10: 479 [in list, Mongolia]; Schmiedeknecht, 1883, Apid. Europe., 1: 521-522 [female \& male]; Nurse, 1904. J. Bombay nat. Hist. Soc., 15: 557 [in list, India].

Andrena (Plastandrena) pilipes: Gusenleitner \& Schwarz, 2002, Entomofauna, (Suppl. 12): 594-597; Tadauchi, 2008, Esakia, (48): 5.

Andrena dolorosa Nurse, 1904, J. Bombay nat. Hist. Soc., 15: 563 [female, Pakistan].

Other synonymies: See Gusenleitner \& Schwarz (2002).

Specimens examined. China: Xinjiang Uygur Autn. Region: 1 female, Alatai, $930 \mathrm{~m}, 14$. viii. 1960 (S-y. Wang); 2 females, Yiwu, 21. vi. 1979 (S-f. Wang). Gansu Province: Wuwei: 1 female and 5 males, 28. iv. 1996 (S. Ikudome); 4 males ( $\mathrm{H}-\mathrm{l}$. Xu); 2 females and 1 male (O. Tadauchi). 30. iv. 1996; 19 females and 2 males (H-l. $\mathrm{Xu}$ ), 17 females and 3 males (O. Tadauchi); 13 females and 4 males (S. Ikudome), 10-11. viii. 1996; Lingtao: 1 female and 2 males ( $\mathrm{H}-\mathrm{l} \mathrm{Xu}$ ); 2 females (S. Ikudome), Daban, 17. viii. 1996. Qinghai Province: Ledu: 2 females (H-l. Xu); 1 female (S. Ikudome), 16. viii. 1996. Beijing: 3 females, 1938 (K. Tsuneki). Inner Mongolia: 1 female, Apaka, 22. viii. 1939 (K. Tsuneki). Mongolia: Ostgobi aimak: 1 female, $20 \mathrm{~km}$ So v. Cojren, 1,200 m, 1. vii. 1963 (Z. Kaszab).

Remarks. This species has two generations a year. It can be recognized by the vestiture wholly blackish to black except the white hind femoral and tibial scopal hairs in female.

Distribution. China: (Qinghai, Xinjiang, Gansu, Inner Mongolia, Beijing); Mongolia; Pakistan; Central Asia; Europe; North Africa.

Floral associations. China: Potentill sp., Brassica campestris, Allium tuberosum.

\section{Andrena (Plastandrena) japonica (Smith)}

Nomia japonica Smith, 1873, Trans. Ent. Soc. London, 1873: 201 [female, Japan].

Andrena japonica: Meado-Waldo, 1916, Ann. Mag. nat. Hist., (8)17: 462; Yasumatsu, 1941, Peking nat. Hist. 
Bull., 15: 277 [in list].

Andrena mitsukurii Cockerell, 1913, Ann. Mag. nat. Hist., (8)11: 186 [male, Japan]; Yasumatsu, 1941, Peking nat. Hist. Bull., 15: 278 [in list].

Andrena (Glyphandrena) mitsukurii: Hedicke, 1933, Mitt. Zool. Mus. Berlin, 19: 213.

Andrena (Mitsukuriella) japonica: Hirashima, 1965, J. Fac. Agr., Kyushu Univ., 13: 472-476; Hirashima, 1966, J. Fac. Agr., Kyushu Univ., 14: 96, 116 [female \& male, in key]; Kim and Kim, 1983, Kor. J. Ent., 13: 6 [Korea]; Tadauchi, 1989, Check List Jap. Insects, 684.

Andrena fukaii Cockerell, 1914, Ann. Mag. nat. Hist., (8)13: 279 [female, Japan]; Yasumatsu, Peking nat. Hist. Bull., 15: 276. New synonymy

Andrena (Glyphandrena) fukaii: Hedicke, 1933, Mitt. Zool. Mus. Berlin, 19: 213.

Andrena (Mitsukuriella) fukaii: Hirashima, 1965, J. Fac. Agr., Kyushu Univ., 13: 476-478; Hirashima, 1966, J. Fac. Agr., Kyushu Univ., 14: 96, 116 [female \& male, in key].

Andrena (Plastandrena) japonica: Gusenleitner \& Schwarz, 2002, Entomofauna, (Suppl. 12): 378-379.

Specimens examined. A series of specimens in the Kyushu University are examined.

Remarks. This species has two generations a year. It is recognized by the metasomal terga coarsely punctate and unusually reflected apically in the 1st generation (summer form), but less reflected in the 2 nd generation (spring form).

Distribution. Japan (Hokkaido, Honshu, Shikoku, Kyushu); Korea.

Floral association. See Hirashima (1965).

\section{Andrena (Plastandrena) transbaicalica Popov}

Andrena (Plastandrena) transbaicalica Popov, 1949, Ent. Rev. USSR., 30: 398 [female, Siberia]; Popov, 1958, Horae. Soc. Ent. Union. Soviet., 46: 135 [female in key]; Osytshnjuk, 1995, Key Insects Russian Far East, Vol. IV, part 1, 493, 518 [female \& male, in key, Russian Far East]; Gusenleitner \& Schwarz, 2002, Entomofauna, (Suppl. 12): 772-773.

Andrena (Plastandrena) astragalina Hirashima, 1957, Mushi, 30: 51 [female \& male, Japan]; 1965, J. Fac. Agr., Kyushu. Univ., 13: 488; Hirashima, 1966, J. Fac. Agr., Kyushu. Univ., 14: 96, 104, 116 [female \& male, in key]. Tadauchi and Lee, 1992, Esakia, (32): 56 [Korea]. (2002)

Other synonymies. See Gusenleitner \& Schwarz

Specimens examined. China: Heilongjiang Province: 1 female and 4 males, Jingpo Lake, Mudanjiang, 23-24. v. 1993 (O. Tadauchi).

Remarks. This species is similar to Andrena tibialis (Kirby) in having sparse punctures on metasomal terga, but it differs by the entire process of labrum and the metasomal terga with scanty hairs in female.

Distribution. China (new record, Heilongjiang Prov.);
Japan (Hokkaido, Honshu, Kyushu); Korea (central Korea); Russia (middle Siberia, Far East area).

Floral association. China: Taraxacum sp.

\section{Andrena (Plastandrena) eversmanni Radoszkowski}

Andrena eversmanni Radoszkowski, 1868, Horae Soc. ent. Ross., 5: 74-75 [female \& male, central Asia); Schmiedeknecht, 1883, Apid. Europe., 1: 434, 475 [female \& male]; Morawitz, 1890, Horae Soc. ent. Ross., 24: 357 [in list, Mongolia]; Yasumatsu, 1941, Peking nat. Hist. Bull., 15: 280 [in list].

Andrena (Plastandrena) eversmanni: Popov, 1958, Horae Soc. ent. Union. Sovet., 46: 131, 140 [female \& male, in key]; Xu and Tadauchi, 1997, J. Fac. Agr., Kyushu Univ., 41: 172-175 [redescription]; Gusenleitner \& Schwarz, 2002, Entomofauna, (Suppl. 12): 257-258; ; Tadauchi, 2008, Esakia, (48): 2-3.

Specimens examined. China: Gansu Province: Nanhu, Dunhuang, 7. v. 1996: 3 females and 2 males (H-l. Xu); 2 females and 2 males (O. Tadauchi); 5 females and 7 males (S. Ikudome). Mongolia: Bejanchongor Aimak, 2 females, 24-29. vi. 1967 (Z, Kaszab).

Remarks. This species is separated from the other members of Plastandrena by hairs on the body abundant, white, the facial fovea white, the mesoscutum and suctellum with subvelvety hairs and the metasomal terga with broad, decumbent hair bands in female.

Distribution. China (new record, Gansu Prov.); Mongolia; Central Asia.

Floral association. Salix sp.

\section{Andrena (Plastandrena) mongolica Morawitz}

Andrena mongolica Morawitz, 1880, Bull. Acad. Sci. St. Petersbourg, 26: 360 [female, Mongolia]; Yasumatsu, 1941, Peking nat. Hist. Bull., 15: 278 [in list].

Andrena (Plastandrena) mongolica: Popov, 1949, Ent. Obozr., 30: 393 [female \& male, Russia]; Popov, 1958, Horae Soc. ent. Union. Sovet., 46: 133, 141 [female \& male, in key]. Xu and Tadauchi, 1997, J. Fac. Agr., Kyushu Univ., 41: 175-176 [redescription]; Gusenleitner \& Schwarz, 2002, Entomofauna, (Suppl. 12): 490: ; Tadauchi, 2008, Esakia, (48): 3-5.

Andrena (Plastandrena) apiformis mongolica: Warncke, 1967, Eos, 43: 289.

Andrena (Plastandrena) ferghanica: Wu, 1982, Insects of Xizhang, P. 381[nec A. mongolica Morawitz, 1880].

Specimens examined. China: Xinjiang Uygur Autn. Region: 1 female, Shache, 26. v. 1955 (S-j. Ma); 1 female, Atushi, 1,350 m, 22. vi. 1987 (X-z. Zhang); 1 female, Aketao, $2950 \mathrm{~m}$, 10. vii. 1989 (X-z. Zhang); 1 male, Hezhen, 1,300 m, 3. vi. 1959 (S-y. Wang). Gansu Province: 1 male, Xishuichi, Zhangye, 2. v. 1996 (H-l. Xu); 4 males, Jiuquan, 3. v. 1996 (S. Ikudome); 4 males (H-l. Xu); 2 females and 1 male (O. Tadauchi); 2 females and 1 male (S. Ikudome), Yumen, Jiayuguan, 4. v. 1996.

Remarks. Wu (1982) misidentified this species as $A$. (Plastandrena) ferghanica Morawitz from Tibet. This 
species is similar to Andrena cypricola Mavromoutakis from Europe, but it can be easily separated from cypricola by the longer flag segmental 3, the coarsely punctate clypeus, the longer malar space and hair bands on the metasomal terga.

Distribution. China (Gansu, Xinjiang, Xizang Provs.); Mongolia; Russia; Central Asia.

Floral association. Prunus sp.

\section{Andrena (Plastandrena) magnipunctata Kim et Kim}

Andrena (Plastandrena) magnipunctata Kim et Kim, 1989, Kor. J. Ent., 19: 201-202 [female, Korea]; Tadauchi et al., 1997, Esakia, (37): 195-196 [male, Korea]; Gusenleitner \& Schwarz, 2002, Entomofauna, (Suppl. 12): 452

Specimens examined. China: Beijing: 1 female, 17. v. 1962 (S-y. Wang); 2 females, 7-28. iv. 1964 (S-m. Gee); 2 females, 4-20. v. 1964 (S-m. Gee); 1 female, 26. iv. 1974 (S-f. Wang); 1 female, 25. viii. 1981 (Q. Zhou). Heilongjiang Province: 2 females, Harbin, 10-20. viii. 1955; 1 female, Jingpo Lake, Mudanjiang, 26. v. 1993 (O. Tadauchi).

Remarks. This species is similar to Andrena transbaicalica, the female can be separated from that of transbaicalica by the metasomal terga with close punctures and white hair bands.

Distribution. China (new record, Beijing, Heilongjiang Prov.); Korea.

Floral association. Not available.

\section{ACKNOWLEDGEMENTS}

We are grateful to Emeritus Prof. Y. Hirashima and Prof. J. Yukawa of Kyushu University for their useful suggestions, to Assoc Prof. L. Westover of Kyushu University for reading the manuscript. Xu HL also thanks to Prof. Wu Yan-ru of Institute of Zoology, Chinese Academy of Sciences for her constant encouragements. This research was supported by the National Natural Science Foundation of China (No. 30970412). This is a contribution from the Entomological Laboratory of Kyushu University (Ser. 6 No. 90).

\section{REFERENCES}

Cockerell, T. D. A. 1913 Descriptions and records of bees. XLIX. Ann. Mag.Nat. Hist., 11(8): 185-195

Cockerell, T. D. A. 1914 Descriptions and records of bees. LVII. Ann. Mag.Nat. Hist., 13(8): 277-286

Gusenleitner, F. and M. Schwarz 2002 Weltweite Checkliste der Bienengattung Andrena mit Bemerkungen und Ergänzungen zu paläarktischen Arten (Hymenoptera, Apidae, Andreninae, Andrena).Entomofauna, Suppl., 12: 1-1280 (In German)

Hedicke, H. 1933 Beiträge zur Systematic der Gattung Andrena F.
(Hym. Apid.). Mitt. Zool. Mus. Berlin, 19: 199-220 (In German)

Hirashima, Y. 1957 Descriptions and records of bees of the genus Andrena from Eastern Asia. III (Hymenoptera, Andrenidae). Mushi, 30: 49-57

Hirashima, Y. 1965 Systematic and biological studies of the family Andrenidae of Japan (Hymenoptera, Apoidea) Part 2. Systematics 5. J. Fac. Agr., Kyushu Univ., 13(3): 461-491

Hirashima, Y. 1966 Systematic and biological studies of the family Andrenidae of Japan (Hymenoptera, Apoidea) Part 2 . Systematics 7. J. Fac. Agr., Kyushu Univ., 14(1): 89-131

Kim, M-l. and C-w. Kim 1983 On the 9 unrecorded Andrenidae from Korea (Hymenoptera: Apoidea). Kor. J. Entomol., 13(1): $5-9$

Kim, M-l. and C-w. Kim 1989 Systematic study of Andrenidae from Korea (Hymenoptera: Apoidea) (On the three new species and one new subspecies). Kor. J. Entomol., 19(3): 199206

Morawitz, F. 1880 Ein beitrag zur bienen-fauna Mittel-Asiens. Bull. Acad. Impér. Sci. St-Pétersbourg, 26: 337-389

Nurse, C. G. 1904 New species of Indian Hymenoptera. Apidae J. Bombay Nat. Hist. Soc., 15: 557-585

Osytshnjuk, A. Z. 1977 Bees-Andrenidae. Fauna Ukraini, 12(5): 1-328 (In Ukrainian)

Osytshnjuk, A. Z. 1995 Andrena. In "Key to the insects of Russian Far East in six volumes. vol. 4, Neuropteroidea, Mecoptera, Hymenoptera, Part 1" ed. by P. A. Lehr, 606 pp, St. Petersburg, Nauka, pp. 489-527 (In Russian)

Popov V. B. 1949 Subgenus Plastandrena Hedicke and its new species (Hymenoptera, Apoidea). Entomol. Obozr., 30: 389404 (In Russian)

Popov V. B. 1958 On three subgenera of the genus Andrena (Hymenoptera, Andrenidae). Hor. Soc. Union. Sovet., 46 109-161 (In Russian)

Radoszkowski, O. 1868 Matériaux pour servir à l'étude des insectes de la Russie, IV. Notes sur quelques Hyménoptères de la tribu des Apides. Hor. Soc. Entomol. Ross., 5: 73-90

Smith, F. 1873 Descriptions of Aculeate Hymenoptera of Japan, collected by Mr. George Lewis at Nagasaki and Hiogo. Trans. Entomol. Soc. Lond., 1873: 181-206

Tadauchi, O. 2008 The genus Andrena from Kazakhstan and Kyrgyzstan (Hymenoptera, Andrenidae) (2). Esakia, (48) $1-18$

Tadauchi, O. and C-e. Lee 1992 The family Andrenidae of Korea (Hymenoptera, Apoidea). 1. Esakia, (32): 47-58

Tadauchi, O. and T. Matsumura 2007 The genus Andrena collected from Nepal (Hymenoptera, Andrenidae) with redescriptions of some types of Andrena described from North India. Esakia, (47): 1-20

Tadauchi, O., H-l. Xu, and J-c. Paik 1997 The family Andrenidae of Korea (Hymenoptera, Apoidea) II. Esakia, (37): 187-202

Warncke, K. 1968 Die Untergattungen der westpaläarktischen bienen-gattung Andrena F. Mem. Est. Mus. Zool. Univ. Coimbra, (307): 1-111 (In German)

Wu Y-r. 1965 Economic Insect Fauna of China. Fasc. 9, Hymenoptera: Apoidea. Science Press, Beijing, 83 pp

Wu Y-r. 1982 Hymenoptera: Apoidea. In "Insects of Xizang Vol. II". Ed. By F. S. Huang, Science Press, Beijing, pp. 379-426

$\mathrm{Xu}, \mathrm{H}-\mathrm{l}$. and O. Tadauchi 1997 Subgeneric positions and redescriptions of East Asian Andrena preserved in the Zoological Institute, Russian Academy of Sciences, St. Petersburg (Hymenoptera, Andrenidae). J. Fac. Agr., Kyushu Univ., 41(3-4): 165-178

Yasumatsu, K. 1941 A list of the Far Eastern species of the genus Andrena (Hym., Apoidea). Peking Nat. Hist. Bull., 15(4): 273-284 